University of California, Hastings College of the Law UC Hastings Scholarship Repository

Faculty Scholarship

2002

\title{
"It's Snowing Down South": How to Help Mothers and Avoid Recycling the Sameness/Difference Debate
}

Joan C. Williams

UC Hastings College of the Law, williams@uchastings.edu

Follow this and additional works at: http://repository.uchastings.edu/faculty_scholarship

Part of the Civil Rights and Discrimination Commons, and the Law and Gender Commons

\section{Recommended Citation}

Joan C. Williams, "It's Snowing Down South": How to Help Mothers and Avoid Recycling the Sameness/Difference Debate, 102 Colum. L. Rev. 812 (2002).

Available at: http://repository.uchastings.edu/faculty_scholarship/792 


\section{Faculty Publications UC Hastings College of the Law Library}

Author: Joan C. Williams

Source: Columbia Law Review

Citation: 102 Colum. L. Rev. 812 (2002).

Title: $\quad$ "It's Snowing Down South": How to Help Mothers and Avoid Recycling the Sameness/Difference Debate

Originally published in COLUMBIA LAW REVIEW. This article is reprinted with permission from COLUMBIA LAW REVIEW and Columbia University School of LaW. 


\title{
RESPONSE ESSAYS
}

\author{
"IT'S SNOWING DOWN SOUTH": HOW TO HELP \\ MOTHERS AND AVOID RECYCLING THE SAMENESS/ \\ DIFFERENCE DEBATE
}

\author{
Joan Williams*
}

\begin{abstract}
Professor Williams argues that by understanding their history feminists can avoid repeating it. The key disagreement in the destructive sameness/ difference debate is not over whether women are the same or different from men, but over whether to empower women in their traditional caregiving role (the "femme strategy"), or to shift them into socially valued masculine gender performances such as melding personal identity with paid work and off-loading care work (the "tomboy strategy"). Professor Williams argues that, given the profound importance of care work to the identities of the $85 \%$ of women who become mothers, and the stmuctural linkage of motherhood and economic inequality, we need to accept as a given that empowering women requires ending the economic marginalization of mothers. She proposes a "listening tour," informed by an epistemology that respects all truths as partial, flawed, and situated-all forged in an arena of constraint. The law professor's role is not to pronounce the "One True Way" but to seek points of respectful coalition among people whose truths differ.
\end{abstract}

\section{INTRODUCTION}

Once upon a time there was a world in which XXs were under intense social pressure to grow ponytails, and most of them did. But no one with a ponytail could get a good job. The good jobs went to XYs.

Some XXs wanted nothing more than to resist the pressure to grow ponytails. Their hearts' desire was for crewcuts.

A social movement arose to enable people with ponytails to get and keep good jobs. But it soon deteriorated into infighting, as XXs who wanted crewcuts protested that the movement to empower ponytails deflected attention from the real issue.

Every time the ponytails argued that they should have access to good jobs, the XXs who wanted crewcuts argued that the ponytails' refusal to cut their hair was hurting those who had the courage to spurn conven-

* Professor of Law and Director of the Program on Gender, Work \& Family, American University, Washington College of Law. My thanks to Kate Silbaugh for reading drafts of this Essay, and to Jim Dempsey for his help and insight. Mistakes that remain are mine alone. Many thanks for timely, precise, thorough, and insightful research assistance from Abby Coleman and Rob Knight. This Essay was made possible by a research grant from the Dean's Summer Research Fund at American University, Washington College of Law. 
tion. "If you want a good job," they said, "you have to be ready, willing, and able to do what XYs have always done to get them."

So the two groups fought. Meanwhile, XYs kept a low profile. They continued to hold most of the good jobs, and the social and financial power that accompanied them.

$* * * * *$

This Essay is a response to Vicki Schultz's Essay, "Life's Work," published last year in the Columbia Law Review. ${ }^{1}$ As the commentator whose "joint property proposal" gives Schultz the name she uses for the group of feminists she critiques, 1 will point out various ways in which she has mischaracterized this proposal. She conflates it with human capital theorists' endorsement of traditional gender roles, and posits a Manichean struggle between the forces of traditionalism and the forces of liberation. In fact, something more subtle is at issue. The clash is not between women's liberation and traditionalism, but between two different models of what women's liberation might mean.

In this Essay, 1 argue that the most promising approach to work/ family issues is not a pronouncement of the importance of work roles by work-identified women, no matter how sincerely felt. What we need instead is a listening tour, followed by rhetoric and proposals that resonate with the lived experience both of women with work identities and of women whose identities stem solely from family roles. We also need a message that reflects the experience of men who feel pinched by a breadwinner role that places them under intense job pressure and attenuates their participation in family life.

Framing such a message requires a familiarity with the literature on workplaces, but it also requires drawing on recent work in pragmatism, gender theory, work/family studies, family sociology, and social psychology. Only through a broad interdisciplinary approach can we avoid recycling the old fashioned and divisive sameness/difference debates of the 1980s.

\section{Femmes and Tomboys: Recycling the Sameness/Difference Debate}

The first two rounds of the sameness/difference debate played out in the 1980s. From the viewpoint of the new millenium, we can understand what was at issue better today than we could then.

Today it is commonplace to distinguish between women and gender performances. This language can help defuse old battles about what women are "really like." For purposes of unpacking the old sameness/difference debate, the key point is that feminists differ in their relationship to femininity. Some are femmes who embrace conventional gender per-

1. Vicki Schultz, Life's Work, 100 Colum. L. Rev. 1881 (2000) [hereinafter Schultz, Life's Work]. 
formances. ${ }^{2}$ For them, the key way to empower women is to end the devaluation of femininity. ${ }^{3}$ Other feminists have a very different vision. ${ }^{4}$ In their view, the key to women's liberation is to empower women to disassociate themselves from disempowered feminine gender performances (including care work), and to replace those behaviors with socially valued masculine gender performances (notably a close identification with paid work and a strategy of off-loading family care work onto one's partner).$^{5}$ Let us call this the strategy of the tomboys. ${ }^{6}$

2. I am proposing to use the term "femme," traditionally used to describe a lesbian committed to a feminine gender performance, to describe any woman committed to a feminine gender performance. I use the term "tomboy" to describe any woman committed to embracing a traditionally masculine gender performance. Joan Williams, Unbending Gender: Why Family and Work Conflict and What to Do About It 177-242 (2000) [hereinafter Williams, Unbending Gender]. My use of these terms is meant to remind women that all of us-gay, queer, and straight-embrace some parts of traditional femininity and struggle with others. We should not let the fact that we embrace and struggle with slightly (or very) different parts divide us against each other.

3. See, e.g., Robin West, Jurisprudence and Gender, in Feminist Legal Theory: Foundations 75, 78 (D. Kelly Weisberg ed., 1993) (associating women with the gender performances enshrined in conventional femininity: "women value intimacy, develop a capacity for nurturance, and an ethic of care"). West proposes to end the devaluation of motherhood by framing a political theory around motherhood. See Robin West, Caring for Justice 1-3 (1997) (using "parenting" as the central metaphor in her social theory).

4. For an example of how calling conventional femininity "the voice of women" creates dissension between the femmes and tomboys, see Jeanne L. Schroeder, Feminism Historicized: Medieval Misogynist Stereotypes in Contemporary Feminist Jurisprudence, 75 Iowa L. Rev. 1135, 1143 n.I2 (I990). Schroeder has written:

West has stated that every woman she knows has recognized herself in In a Different Voice. I literally recognized myself in the book and not in the way that West suggests. When I was a college student I participated in one of the psychological surveys discussed in the book. ... I was one of the women who gave the "archetypical" masculine response. . . My "different voice" and the voices of other women in the study who gave similar unladylike responses (and the male subjects who gave "sissy" answers), even if we were in the minority, apparently were not worthy of discussion ....

Id. Again, "women's voice" is not the voice of women; it is the voice of gender-typical femininity. Calling it "women's voice" offends gender-atypical women, and makes it difficult to create coalitions between femmes and tomboys.

5. See Schultz, Life's Work, supra note 1, at I 883 (advocating an identity focused on paid work); id. at 1906 (advocating the strategy of off-loading care work onto one's partner). In fact, Schultz represents a very pure form of what I have called fullcommodification feminism. Williams, Unbending Gender, supra note 2, at 40-54. One characteristic elision of this tradition that Schultz admits to inherit is the failure to grapple with the widespread sense that some forms of family work are not commodifiable. Schultz, Life's Work, supra note 1, at 1901 n.68. Schultz, however, shows no sign of reconciling this insight with her well-worn advocacy of collectivizing housework. Id. at 1898 . Nor does she respond to the argument that full collectivization of care work is an undesirable strategy because it perpetuates race and class hierarchies. See Williams, Unbending Gender, supra note 2, at 145-76 (discussing in depth this argument); Dorothy Roberts, Spiritual and Menial Housework, 9 Yale J.L. \& Feminism 5I, 55-56 (1997) (offering most representations of this argument).

6. See Williams, Unbending Gender, supra note 2, at 177-242. 
With this analysis in place, we can see that the 1980s "special versus equal treatment" debate over the design of maternity policies pitted femmes (whose chief concern was to empower women in their traditional caregiving roles) against tomboys (whose chief concern was to ensure that those women who performed like men were not undermined by policies that treated women as different from men). ${ }^{7}$ The tomboys' focus was on women committed to adopting traditionally masculine gender performances, whereas the femmes' focus was on women committed to giving traditionally feminine gender performances. ${ }^{8}$

The "different voice" debate was another fight between the femmes and the tomboys. ${ }^{9}$ Carol Gilligan, who gave this strain of feminism its twentieth-century voice, wanted to ensure that the voice of conventionally gendered women was not belittled in the name of norms framed around the gender performances of conventional men. ${ }^{10}$ She and her followers wanted not so much to change women as to make the world a more hospitable place for femmes. ${ }^{11}$ Tomboys, myself included, bristled when conventionally feminine gender performances were dubbed "the voice of women." 12

The past year has shown that we have begun to recycle the sameness/difference debate. The new round, thus far, follows a familiar pattern. Feminists committed to making traditionally masculine gender performances available to women are pitted against feminists committed to decreasing the costs of conventionally feminine gender performances. This explains two recent exchanges in the Columbia Law Review. The first is between Martha Fineman, whose analysis of gender focuses on motherhood, and Katherine Franke, who is committed to opening up space for women to eschew motherhood in favor of the traditionally masculine path of framing an identity primarily around sexuality. ${ }^{13}$ The second is the current exchange, between Schultz, who is committed to opening up space for women to adopt the traditionally masculine path of framing an

7. Id. at 217-32.

8. Id. at 226-31 (tomboys are "equal parenting advocates"; femmes are "maternalists").

9. Id. at $\mathbf{1 8 3 - 8 6 .}$

10. See, e.g., Carol Gilligan, In a Different Voice 17-23 (1982) (arguing that women's "different voice" is not simply a less advanced form of morality). Williams, Unbending Gender, supra note 2, at 178-83. My thanks to Kate Silbaugh for the insight that what Gilligan did was to give this strain of feminism its twentieth-century voice.

11. Williams, Unbending Gender, supra note 2, at 178-83.

12. See generally Joan C. Williams, Deconstructing Gender, 87 Mich. L. Rev. 797, 799-800 (1989) (critiquing Carol Gilligan's “different voice”). I have proposed to defuse this conflict by having "different voice" feminists talk not about "the voice of women" but rather "the voice of traditional femininity." As of yet, few have taken up the suggestion.

13. See generally, Martha Albertson Fineman, The Neutered Mother, The Sexual Family, and Other Twentieth-Century Tragedies (1995) [hereinafter Fineman, The Neutered Mother]; See Katherine M. Franke, Theorizing Yes: An Essay on Feminism, Law, and Desire, 101 Colum. L. Rev. 181, 205 (2001). 
identity primarily around paid work, ${ }^{14}$ and the care work feminists she critiqued in "Life's Work". ${ }^{15}$

Which is the "True Feminist Way": to empower women in their feminine roles, or to enable women to invest their identities instead where men traditionally have?

\section{Shouldn't feminism do both?}

Feminism is a loose coalition of many women who are dissatisfied with traditional gender constraints for a variety of reasons. Some are tomboys, dissatisfied that they are not allowed crewcuts. Some are femmes, dissatisfied that ponytails are costly.

Women are disadvantaged in both ways. ${ }^{16}$ The agenda of empowering the ponytails is quite simply different-not better, not worse, just dif-

14. Schultz, Life's Work, supra note 1, at 1900-15.

15. See, e.g., Joan C. Tronto, Moral Boundaries: A Political Argument for an Ethic of Care 157 (1994) ("Because our society does not notice the importance of care and the moral quality of its practice, we devalue the work and contrihutions of women . . . only if we understand care as a political idea will we be able to change its status and the status of those who do caring work in our culture."); Williams, Unbending Gender, supra note 2, at 55 ("We need to ... chang[e] the definition of the ideal worker so that it reflects the norm of parental care. Instead of simply allowing women to work on the same terms traditionally available to men, we need to change the conditions under which both men and women work."); Martha M. Ertman, Commercializing Marriage: A Proposal for Valuing Women's Work Through Premarital Security Agreements, 77 Tex. L. Rev. 17, 29 (1998) ("The twin problems of displaced homemaker indigency and devaluation of female labor are largely gender-related. While a single legal innovation cannot disrupt entrenched gender inequality, measures directed toward commodifying homemaking have the potential to contribute significantly to the alleviation of inequities."); Martha Albertson Fineman, Contract and Care, 76 Chi.-Kent L. Rev. 1403, 1411-12 (2001) ("[E]ven though there may be some recognition that caretaking is of public benefit, no compensation and scant accommodation have been given to caretakers by societal institutions other than the family. . . This injustice can only be addressed by policies that both subsidize and accommodate caretakers."); Martha Albertson Fineman, Cracking the Foundational Myths: Independence, Autonomy, and Self-Sufficiency, 8 Am. U. J. Gender Soc. Pol'y \& L. 13, 18-19 (2000) ("[C]aretaking work creates a collective or societal debt. . . . The mandate that the state ... respond to dependency . . . is not a matter of altruism or empathy ..., hut one that is primary and essential because such a response is fundamentally societypreserving."); Katharine Silbaugh, Turning Labor into Love: Housework and the Law, 91 Nw. U. L. Rev. 1, 5 (1996) ("[D]enying housework its status as work is costly to those who perform it. A consistent account within the law of housework's economic value would benefit those who perform the work-predominantly women."). See generally Symposium on the Structures of Care Work, 76 Chi.-Kent L. Rev. 1389 (2001) (arguing for the recognition of a new field of inquiry in feminist jurisprudence). Schultz says that " $[n] \circ$ self-respecting feminist could be against 'valuing housework," Schultz, Life's Work, supra note 1 , at 1990, but her article ducks some hard questions on how to do so. While she acknowledges in a single sentence that the full-commodification strategy may have some limitations, id. at 1902 ("There may, of course, be some forms of household labor that cannot or should not be commodified."), she never explores the subject further. Exploring these limits is a crucial issue that cannot be dismissed.

16. Compare sources cited in supra note 15, with Mary Anne Case, How High the Apple Pie? A Few Troubling Questions About Where, Why, and How the Burden of Care for Children Should Be Shifted, 76 Chi.-Kent L. Rev. 1753, 1757-59 (2001) (detailing how 
ferent-from the agenda of allowing women crewcuts. If we insist on sanctifying the "One True Way," we will only deflect our energy away from achieving gender change into the sameness/difference debate and other fights among feminists.

lmporting these gender wars into feminist jurisprudence will help none of us. Nor will they be easy to avoid. The first step is for care work theorists to remember that women without children suffer daily affronts because of the societal expectation and celebration of motherhood. As Mary Anne Case has shown so eloquently, it is a bit much for a woman without children to be both maligned and belittled for being "childless" and also expected to sacrifice for OPC ("other people's children"). ${ }^{17}$ This situation is particularly galling when the woman in question has heavy care work responsibilities that are ignored by proposals to value care work that focus on child care to the exclusion of other forms of family work (for example, caring for parents or seriously ill partners). ${ }^{18}$

Care work advocates not only need to respect the daily affronts faced by nonmothers. They also need to formulate policy proposals that are not limited to mothers or even to women. Human resource professionals point out that the most effective way to implement a work/life program is to ask not why a given worker wants flexibility, but whether the specific proposal will meet the employer's legitimate business needs. ${ }^{19}$ If an employee can make a valid business case for flexibility, why should the employee's motivation matter? ${ }^{20}$ The key is to replace the marginalized mommy tracks available today with a variety of possibilities that offer flexibility without marginalization. ${ }^{21}$ Only when flexibility is no longer associ-

women without children are disadvantaged by measures designed to help primary caregivers).

17. 1d. at 1754 n.5, 1755 n.7, 1757 (“'[T] he existing employees' on whom the 'excess work' resulting from schedules favoring mothers on the job is 'dumped' are other women, most likely women without children"). Katherine Franke used the phrase "OPC" at the "Hegemonic and Resistant Genderings: Changing the Relationship of Market Work to Family Work," Gender, Work \& Family Project, American Univ.-Washington College of Law, Washington, D.C., June 4-6, 1999.

18. Case, supra note 16 , at 1754 n.5.

19. Williams, Unbending Gender, supra note 2, at 98.

20. The backlash against family friendly policies stems from situations where employers allow a mother to go part-time, pocket the part of her salary she is no longer paid, and then overwork the remaining employees without additional compensation. This is not a way to implement a family-responsive policy; it is a way to sabotage one. See Elinor Burkett, The Baby Boon 38-44 (2000) (attacking family friendly workplaces on the grounds they "cheat the childless").

21. Most "family friendly" programs today suffer from very low usage rates because they marginalize those who use them. For an analysis of how family friendly programs offered by law firms marginalize those who use them, see Joan Williams \& Cynthia Thomas Calvert, Balanced Hours: Usable Part-Time Policies for Washington Law Firms, Final Report of the Project on Attorney Retention 14, 16-19, 20-41 (2001), available at http:// www.pardc.org/final_report.htm (on file with the Columbia Law Review) (detailing how part-time policies at law firms marginalize the attorneys who use them, introducing the 
ated with career suicide will men begin to feel free to break out of the ideal worker role so many find constraining and oppressive. ${ }^{22}$

Just as it is important for care work advocates to respect the daily affronts faced by nonmothers, women without children need to remember that the gender system that leads them to be treated as if they are somehow defective because they are not mothers simultaneously leads women who are mothers into marginalization and relative poverty. ${ }^{23}$ Both groups have a stake in the deconstruction of domesticity. ${ }^{24}$

\section{What Do Joint Property Advocates Advocate?}

Schultz describes a group she calls joint property advocates, who tend "to reify traditional male-breadwinner, female-homemaker patterns in a way that closes down, rather that opens up, strategies for change," so that:

the only viable approach becomes the separate-but-equal one of paying women to do housework, while leaving unexamined the broader economic and political forces which deprive women of the bargaining power necessary to obtain a more egalitarian sharing of labor in their households, and which prevent us from building a political system that provides the public support necessary for women and men to lead more balanced lives. ${ }^{25}$

Joint property theorists make "traditional gender-based arrangements for household labor appear inevitable, [thereby making] . . . it seem impossible to reshape social life to structure family life in more egalitarian ways." 26 Schultz protests against this "attempt to revive the familywage system" and to "provide even more encouragement for women to invest in patriarchal relationships." 27 She links joint property advocates with the work of conservative human capital theorists, noting their "failure to take women seriously as workers," 28 with policies that "reproduce the very gender-based patterns of labor that create women's disadvan-

"PAR usability test" to enable employers to assess whether their policy marginalizes those who use it, and articulating a model policy that avoids marginalization).

22. Williams, Unbending Gender, supra note 2, at 1 (noting that the idealized worker is someone who works full-time and overtime and takes little or no time off for childbearing or childrearing); see also id. at 25-30 (documenting the oppressive elements of the ideal worker role); id. at 59 (showing that a high percentage of men would prefer to cut back on work hours in favor of more family or personal time).

23. See discussion infra notes 95-99 and accompanying text.

24. In drafting this Essay, I consciously avoided focusing on issues relating to poor women and women of color because a recognized expert had agreed to write on these subjects in this volume. Unfortunately, due to circumstances surrounding September 11, that essay was never submitted. This unfortunate circumstance in no way is meant to imply that the important issues surrounding care work-both the problems and the solutionscan be adequately discussed without considering race and class dimensions.

25. Schultz, Life's Work, supra note 1, at 1905-06.

26. Id. at 1905 .

27. Id. at 1908 .

28. Id. at 1899 . 
tage[;]"29 the assumption "that housework is, and will continue to be, "women's work'[;]"30 the view that "women care more about children [;]"31 and with a dismissal of the goal of involving men in household work as unrealistic. ${ }^{32}$

Schultz sees little difference between joint property advocates and difference feminists such as Christine Littleton, ${ }^{33}$ who in 1987 proposed an "equality as acceptance" model designed to end the penalties associated with women's caregiving roles. ${ }^{34}$ Joint property advocates, like accommodationists, "appear to be relatively untroubled by the segregationist implications" of their proposals, according to Schultz. ${ }^{35}$ Not only does she see little difference between joint property advocates and difference feminists, she also notes few differences between either group and neotraditionalist human capital theorists who embrace traditional gender roles as normatively desirable ("efficient") ${ }^{36}$

Schultz's survey is curious from my perspective because 1) it misdescribes the joint property proposal as an embrace of traditional gender roles; ${ }^{37}$ 2) it glosses over the shared ideal of an egalitarian thirty hour workweek; ${ }^{38} 3$ ) it makes assertions about family dynamics that do not cite or respond to the relevant scholarly literatures; ${ }^{39}$ and 4) it ignores recent work documenting that a significant proportion of women's economic disadvantage is attributable to their family roles. ${ }^{40}$

\section{A. Does the Joint Property Proposal Embrace Traditional Gender Roles?}

Originally published in the Georgetown Law Review in 1994, the joint property proposal is a regime for income-sharing after divorce. ${ }^{41}$ The analysis begins by noting that husbands in what 1 call the "dominant family ecology" could not perform as ideal workers without a flow of family work from their wives. ${ }^{42}$ Thus the ideal-worker wage (typically nearly seventy percent of the family income $)^{43}$ embeds the woman's labor as well as

29. Id. at 1900 .

30. Id. at 1905 .

3I. Id.

32. Id.

33. Id. at 1955 .

34. Christine A. Littleton, Reconstructing Sexual Equality, 75 Cal. L. Rev. 1279, 1301 (I987).

35. Schultz, Life's Work, supra note I, at 1955.

36. Id. at 1903 .

37. Id. at 1954 .

38. Id. at 1957.

39. Id. at 1905 .

40. Id. at I902-03.

4I. Joan Williams, Is Coverture Dead? Beyond a New Legal Theory of Alimony, 82 Geo. L.J. 2227, 2253-66 (1994) [hereinafter Williams, Is Coverture Dead?].

42. Id. at $2236-37$.

43. Williams, Unbending Gender, supra note 2, at 60 . More recent calculations fix fathers' share of family income at sixty-eight percent. I would like to thank Steve Hipple, who calculated the current figures using the Bureau of Labor Statistics and Bureau of the 
the man's. For this reason, the wage should be treated as a family wage, replacing the current "he who earns it, owns it" rule that now treats it as the sole personal property of the husband, ${ }^{44}$ thereby impoverishing divorced women and their children. ${ }^{45}$

The joint property proposal is carefully designed to give not only the divorcing woman, but also her husband or ex-husband, the motivation to assure that she develops and sustains a serious job involvement. ${ }^{46}$ The proposed entitlement is designed so that the more marginalized a divorced man's ex-wife remains, the more of "his" income will be owned by her in the event of divorce. The joint property proposal therefore creates a significant incentive for the man to support the employment efforts of his wife or ex-wife.

This is clearly not a regime designed to perpetuate traditional gender roles, as I noted in the initial proposal itself. ${ }^{47}$ The former wife's incentive is that, in the case of the prototypical divorce (after four years and two children), ${ }^{48}$ income sharing will end a short time after the children cease to be dependent, leaving the woman to support herself on her own. ${ }^{49}$ Husbands also have an incentive to ensure that both parents do market work, because the more an ex-wife earns, the less the ex-husband will have to pay to achieve income equalization..$^{50}$ Schultz makes no mention of any of this.

Census' Current Population Survey (Mar. 2000), available at http://www.bls.census.gov/ cps/cpsmain.htm (on file with the Columbia Law Review) [hereinafter Current Population Survey].

44. Williams, Is Coverture Dead?, supra note 41 , at 2250-52.

45. Nearly forty percent of divorced women end up in poverty, more than twice the national poverty rate. Demie Kurz, For Richer for Poorer: Mothers Confront Divorce 3 (1995). Schultz worries that giving women joint ownership of the ideal-worker wage will exacerbate economic disparities among women. Schultz, Life's Work, supra note 1, at 1912 ('UJ]oint property feminists tie homemakers' pay to their spouses' income-a methodology that introduces severe class bias."). She does not note, however, that the only alternative is leaving family wealth disproportionately in the hands of men. While social redistribution may well be a desirable goal, leaving women poor while men remain rich hardly seems a desirable strategy for achieving it.

46. If Schultz is advocating eliminating post-divorce entitlements, her proposal recycles an earlier round of the sameness/difference debate: Herma Hill Kay's 1987 proposal to eliminate alimony for younger women on the grounds that preserving alimony only encourages dependence. Herma Hill Kay, Equality and Difference: A Perspective on No-Fault Divorce and Its Aftermath, 56 U. Cin. L. Rev. 1, 80 (1987). Kay quickly backed off her proposal after a firestorm of opposition. Herma Hill Kay, Commentary: Toward a Theory of Fair Distribution, 57 Brook. L. Rev. 775, 763 (1991). See Williams, Unbending Gender, supra note 2, at 222.

47. Williams, ls Coverture Dead?, supra note 41, at 2261-62.

48. Id. at 2261 .

49. Id. at 2262.

50. Id. 


\section{B. The Egalitarian Thirty Hour Workweek}

Schultz distinguishes herself from those who embrace traditional gender roles by holding up an egalitarian thirty hour workweek as her ideal. ${ }^{51}$ The irony is that, unnoted by her, 1 do too. My joint property proposal is linked with a proposal to restructure market work that posits a rosy vision of two parents each working a thirty hour week. ${ }^{52}$

Schultz's amputation of the joint property proposal from the proposal to restructure market work is particularly troubling because the two proposals (published in successive chapters of the same book) are designed to work together, based on my analysis of gender wars among women and gender pressures on men. ${ }^{53}$

Central to my analysis of domesticity (my term for what Schultz calls the "family-wage system") ${ }^{54}$ is the contention that, as a gender system, it creates fights among women that have hobbled feminists' political effectiveness. ${ }^{55} 1 \mathrm{t}$ is to avoid "gender wars" that 1 link a proposal designed to appeal to women whose identities are framed solely around family roles (the joint property proposal) with a proposal designed to appeal to women who also identify with paid work (the proposal to restructure market work). ${ }^{56}$ The goal is to send the message that all women, employed or not, are disadvantaged by the erasure of care work. Both mothers at home full time and employed women have responded positively to my book, Unbending Gender, suggesting that my approach does have potential to defuse the bitter "mommy wars" and build a coalition among women. ${ }^{57}$

Linking the two proposals is designed not only to unite women, but to change gender pressures on men. The joint property proposal is designed to eliminate the carrot that keeps men in traditional roles, while the proposal to restructure market work is designed to eliminate the stick. $^{58}$

51. Schultz, Life's Work, supra note 1 , at 1957 n.305.

52. Williams, Unbending Gender, supra note 2, at 100.

53. Intriguingly, Schultz fails to cite chapter three of Unbending Gender, where I discuss my proposal to restructure market work. She also cites to a law review article published in Harvard Blackletter without giving any indication she knows that the same material appeared as my chapter five. See Schultz, Life's Work, supra note 1, at 1910 n. 105 .

54. Schultz, Life's Work, supra note 1, at 1913.

55. Williams, Unbending Gender, supra note 2 , at 145-76.

56. Id. at 174 .

57. For example, 1 have been invited to make keynote speeches at conferences of "sequencing" mothers and of female lawyers. Joan Williams, Celebrating Mothers' Choices: Making New Ones, Keynote Speech at the Conference of Mothers \& More (Oct. 19, 2001) (Mothers \& More is a grassroots organization of mothers at home full time); Joan Williams, Do you have a Usahle and Effective Balanced Hours Policy?, Keynote Speech at Colorado Women's Bar Association Annual Conference (May 19, 2001).

58. One does not have to delve deeply into Unbending Gender to worry about the accuracy of Schultz's claim that joint property theorists "rarely . . . attempt to question whether overwork is harmful to men too." Schultz, Life's Work, supra note 1, at 1955. I discuss the toll on men not only on the cover, where I say that our current system is "bad 
The carrots that keep men in the ideal-worker role are the current incentives that make it relatively riskless for men to overinvest in market work and underinvest in family relationships. This skewed investment strategy today is artificially costless for men, who can insist (explicitly or implicitly) that their wives or girlfriends marginalize themselves, secure in the knowledge that they will never have to share the financial penalty associated with that marginalization. The joint property proposal changes this by eliminating a father's right to "walk with his wallet" and offer a new (and typically younger) wife the chief family asset produced by the dominant family ecology in his first marriage: the ideal-worker wage. ${ }^{59}$

Linked with the proposal to eliminate the carrot is a proposal to eliminate the stick that keeps men in ideal-worker roles: employers' ability to punish anyone who does not perform as an ideal worker, putting work before family full-time, full-force for forty years. ${ }^{60}$ Schultz herself acknowledges this stick when she notes that men who do fifty percent or more of the household work suffer a "substantial earnings penalty." 61

Given gender pressures on men, notably the regrettable extent to which " $[\mathrm{m}]$ asculinity is measured by the size of a paycheck," 62 most men will not feel able to cut back on job commitments in order to share equally at home so long as workers are offered only two alternatives: ideal worker or wipe-out. What we need is a "Third Path" that offers proportional pay, benefits, training, and advancement for proportional work ("part-time parity") instead of a wipe-out. ${ }^{63}$ These are the requirements for bringing to life the ideal of a shared thirty hour workweek. Few men will work a thirty hour week so long as that schedule is considered a marginalized mommy track that carries steep compensation penalties (often including the elimination of benefits) and an end to career progress.

If Schultz is arguing, as she sometimes seems to be, that everyone should be required to work no more than thirty hours per week, ${ }^{64}$ it would be informative to know how she intends to forbid those who want to work

for men, worse for women, and worst of all for children," but also in chapters one and two. Indeed, one of the hallmarks of Unbending Gender is its argument that feminists need to also focus their attention on gender pressures on men.

59. Williams, Unbending Gender, supra note 2, at 124-31.

60. See id. at 66-81 (detailing masculine norms in market work).

61. Schultz, Life's Work, supra note l, at 1907.

62. Williams, Unbending Gender, supra note 2, at 25 (quoting Robert E. Gould, Measuring Masculinity by the Size of a Paycheck, in Men and Masculinity 96, 96 (Joseph Pleck \& Jack Sawyer eds., 1974)).

63. See generally ThirdPath Institute, Redesigning Work, at http://www.thirdpath. org/redesignsing_work.htm (last visited Mar. 10, 2002) (on file with the Columbia Law Review) (assisting with redefining job options and flexibility). Schultz also appears to embrace the goal of proportional benefits for part-time work without noting that some "joint property feminists" do so, too. Schultz, Life's Work, supra note 1, at 1956.

64. Schultz, Life's Work, supra note 1, at 1956-57. 
more from doing so. Even in European countries that have adopted a thirty-two or thirty-five hour week, high-level managers and professionals-disproportionately male-typically work longer hours. ${ }^{65}$

Assuming that Schultz's proposal is not a prohibition but an amendment to the Fair Labor Standards Act ${ }^{66}$ that would require employers to pay double time after thirty or thirty-five hours and would apply to managerial as well as nonexempt employees, the proposal sounds more different from my approach than it is in practice. Because no significant constituency now exists for Schultz's proposal, she is left where I am, trying to build a coalition in support of "a new cultural ideal that would allow both women and men more time for home, community, and nation." 67

Introducing a bill that requires a thirty hour workweek may not be the most effective approach for cultural reasons: In our immigrant culture, virtue has long been linked with "hard work." 68 Moreover, a new law requiring the most powerful men in the country to pay overtime for any hours worked in excess of a forty hour week whenever their staffs leave Capitol Hill, Wall Street, or Silicon Valley at midnight hardly seems a slam dunk.

An alternative is to create nonmarginalized alternative work schedules (some of which will be "part-time" schedules of forty hours per week). These alternative work schedules could be expected to attract significant numbers of men, based on polls that report that many men (particularly those who work long hours) would prefer to work fewer hours. ${ }^{69}$ Narrative sociology also reports that many men are under new and hydraulic pressure to increase their contributions to family work, ${ }^{70}$ which recent demographic research ${ }^{71}$ suggests will often require cutting back

65. Juliet Webster, Reconciling Adaptability and Equal Opportunities in European Workplaces: Report for DG-Employment of the European Commission 26 (April 2001), available at http://europa.eu.int/comm/employment_social/equ_opp/documents/ reconcil_webster.pdf (on file with the Columbia Law Review).

66. The Fair Labor Standards Act currently requires employers, unless specifically exempted, to pay covered employees overtime for time worked beyond forty hours in a workweek at a rate of at least one and one-half times the regular rate. 29 U.S.C. $\$ 207$ (1994).

67. Schultz, Life's Work, supra note 1, at 1957.

68. Long work hours are linked not only with the diligence of immigrants who came to America to "get ahead," but also with the dignity of professional status. See, e.g., Sara Rimer, Raid and Investigation Unite City for Immigrant, N.Y. Times, Dec. 8, 2001, at A9 (detailing story of hardworking immigrant, who is quoted as saying, "We're management. . . We work $24 / 7^{\prime \prime}$ ).

69. Williams, Unbending Gender, supra note 2, at 59 .

70. Lillian B. Rubin, Families on the Fault Line 77, 83-84 (1994) (noting that one of the key differences between her 1976 and 1994 studies of working-class families is the increased pressure on men to contribute equally to household work).

71. See, e.g., Liana Claire Sayer, Time Use, Gender and Inequality: Differences in Men's and Women's Market, Nonmarket, and Leisure Time 183 (2001) (unpublished Ph.D. dissertation, University of Maryland) (on file with the Columbia Law Review) (arguing that "mothers' time in housework and child care is less responsive to time pulls from market work" than fathers'); see also Suzanne M. Bianchi et al., Is Anyone Doing the 
on the long hours of overtime that nearly one-fourth of fathers work. ${ }^{72}$ Creating a Third Path that provides an alternative to the "ideal worker or wipe-out" syndrome could help achieve the "new cultural ideal" proposed by Schultz.

\section{Family Dynamics and Sex Discrimination}

1n "Life's Work" and in earlier law review articles, Schultz demonstrates a sophisticated understanding of the workplace dynamics that have kept women out of traditionally masculine jobs, and an impressive command of the relevant legal and sociological labor literature. ${ }^{73}$ "[E] arly socialization is a necessary but insufficient condition to account for sex segregation at work," concluded Schultz in 1990, summarizing the work of one researcher. ${ }^{74}$ "Keeping women in their place economically requires a lifelong system of social control that must be exercised powerfully within the workplace itself." 75

Note how Schultz's source posits a multicausal analysis: workplace dynamics plus socialization. Yet in the conclusion to her 1990 article, Schultz appears to conclude that women's employment patterns reflect workplace dynamics alone: "In a very real sense, employers create women's job preferences." 76

The important insight that workplace dynamics play a role in creating women's employment preferences does not prove that workplace dynamics alone account for women's economic position. Yet in "Life's Work," Schultz posits an either/or dichotomy between "scholars [who] argue that women's economic disadvantage arises from their primary commitment to their families" and scholars (like Schultz herself) who argue that women's economic disadvantage arises "from sexist dynamics in labor markets and firms."77

This is a false dichotomy. One can argue that women's economic disadvantage stems both from sexist dynamics in labor markets and firms and from other dynamics as well (including, but not limited to, family

Housework? Trends in the Gender Division of Household Labor, 79 Soc. Forces 191, 216 tbl.5 (2000) (demonstrating that as husbands' hours of market work rise, their household contributions diminish).

72. I would like to thank Steve Hipple for also calculating these figures regarding fathers' work hours from the Current Population Survey, supra note 43.

73. See Schultz, Life's Work, supra note 1, at 1903; Vicki Schultz, Reconceptualizing Sexual Harassment, 107 Yale L.J. 1683, 1748-55 (1998) [hereinafter Schultz, Reconceptualizing Sexual Harassment]; Vicki Schultz, Telling Stories about Women and Work: Judicial Interpretations of Sex Segregation in the Workplace in Title VII Cases Raising the Lack of Interest Argument, 103 Harv. L. Rev. I749, 1815-40 (1990) [hereinafter Schultz, Telling Stories].

74. Schultz, Telling Stories, supra note 73, at 1824 (citing Jerry A. Jacobs, Revolving Doors: Sex Segregation and Women's Careers 48 (1989)).

75. Id.

76. Id. at 1841 .

77. Schultz, Life's Work, supra note 1, at 1900. 
dynamics). This is what I have attempted to do in Unbending Gender. I posit a multicausal model, in which I explore not only sexist workplace dynamics-which include labor markets and firms that define the ideal worker as someone without responsibilities for family work ${ }^{78}$ - but also other causes of women's disadvantaged economic position, including gender pressures on men, gender pressures on women, and the lack of suitable public supports for childrearing and other care work. ${ }^{79}$

In Schultz's prior studies, which focused on women's absence from traditionally masculine jobs, her monocausal model had few ill effects. In "Life's Work," however, Schultz has expanded her focus from women in traditionally masculine jobs to women in general. This shift of topic requires a more complex model and an examination of literatures other than those Schultz has relied on in the past.

It is hard, first, to see how one can speak with such authority on the interaction of work and family roles without engaging with the extensive work/family literature. ${ }^{80}$ Nor does she engage the extensive family law literature on the persistence of traditionalist family roles and the consequent need for post-divorce entitlements. ${ }^{81}$ Gender theory offers additional relevant literatures. The best known is Judith Butler's metaphor of gender as performative, which has been cited in law review articles to help explain family dynamics that affect women's relationship to employment. ${ }^{82}$ Sociologists have developed the closely related metaphor of "doing gender." ${ }^{83}$ Less well known, but perhaps most useful, is Kay Deaux's

78. Note that one need only deny the role of women's family roles if one leaves unchallenged employers' right to define the ideal worker as someone without family responsibilities. My argument is that this definition is an integral part of sexist workplace dynamics.

79. Williams, Unbending Gender, supra note 2, at 25-37, 235-39.

80. Due to space constraints, 1 will refer the reader to my review of the work/family literature in chapters one through three of Unbending Gender, supra note 2, at 276-303 (citing more than fifty work/family studies). Schultz cites very little of the massive academic literature. Instead, she relies largely on a single book, Rosalind C. Barnett \& Caryl Rivers, She Works/He Works (1996).

81. For a review of the relevant family law literature as of 1994, see Williams, ls Coverture Dead?, supra note 41 , at 2227 n.1 (citing more than twenty books and articles discussing post-divorce impoverishment of women due to the persistence of traditional gender roles). It should be noted that much more family law literature has been published since.

82. The germinal work is Judith Butler, Gender Trouble (1990). For an example of the use of Butler's work in a law review article relating to caretaking, see Naomi R. Cahn, Gendered ldentities: Women and Household Work, 44 Vill. L. Rev. 525, 532 (1999) ("The concept of gender performance has various meanings, depending on the context. Within feminist critical theory, it generally refers to the practice of constructing gender through conduct associated with that gender."); Naomi R. Cahn, The Power of Caretaking, 12 Yale J.L. \& Feminism 177, 184 nn.30-31 (2000) [hereinafter Cahn, Power of Caretaking].

83. See, e.g., Candace West \& Don H. Zimmerman, Doing Gender, in The Social Construction of Gender 13, 13-15 (Judith Lorber \& Susan A. Farrell eds., 1991) (proposing a model of gender as produced in the course of social interactions rather than as a stable identity). 
work in social psychology theorizing gender as social interaction. Deaux's model, which highlights the complex interactions between internal states, social roles, status, power, and outside institutional forces, eschews monocausal explanations. It could be very helpful in pinpointing the complex interactions between power and status allocations of men and of women, institutional forces such as sexist labor market dynamics and the lack of social supports for childrearing, and internal states and social roles that create sustained gender pressures on men as well as women. ${ }^{84}$

Schultz's failure to grapple with the work/family literature, the family law literature, and gender theory impedes her analysis in several ways. First, her confidence that "women cannot afford to specialize in homemaking at the expense of paid employment" 85 overlooks the persistence of traditional gender roles: One out of four mothers aged twenty-five to forty-four is still a homemaker, ${ }^{86}$ and the less affluent the mother the more likely she is to be out of the labor force. ${ }^{87}$ Second, Schultz's confidence that "women are . . . satisfied with their diverse roles," 88 glosses over the extensive literature documenting that many women experience acute and painful work/family conflict, as is evidenced by the way my book, Unbending Gender, has been cited by family therapists. ${ }^{89}$ Third, Schultz fails to grapple with evidence that many women may well find an allencompassing identification with market work alienating because they retain commitments to caregiving and other traditionally feminine gender performances. ${ }^{90}$ Finally, Schultz's opposition to post-divorce entitlements for women on the grounds that they "provide even more encouragement for women to invest in patriarchal relationships"91 glosses over

84. See, e.g., Kay Deaux \& Marianne Lafrance, Gender, in 1 The Handbook of Social Psychology 788, 790 (T. Gilbert et al. eds., 1998) (articulating a complex model of gender).

85. Schultz, Life's Work, supra note 1 , at 1908.

86. Williams, Unbending Gender, supra note 2, at 2.

87. Joan Williams, Afterword: Exploring the Economic Meanings of Gender, $49 \mathrm{Am}$. U. L. Rev. 987, 1019-20 tbls.1 \& 2 (1999).

88. Schultz, Life's Work, supra note 1, at 1907 (quoting Barnett \& Rivers, supra note 80 , at 29$)$.

89. For evidence that many women experience acute and painful work/family conflict, see Williams, Unbending Gender, supra note 2, at 16-19, 48-49, 146-47, 153-57. For evidence of how Unbending Gender has been taken up by family therapists, see, e.g., Ashley Harvey, An Interview with Joan Williams, $13 \mathrm{~J}$. Feminist Fam. Therapy (forthcoming Spring 2002); Ashley Harvey, Book Review of Unbending Gender, Amazon.com, at http:// www.amazon.com/exec/obidos/ASIN/0195147146/qid =1014081822/sr=8-1/ref=sr_8_3_ 1/002-8152448-6461626 (last visited Mar. 10, 2002) (on file with the Columbia Law Review) ("Critical information for family therapists. . . . Williams' book has important implications for family therapy, as many male and female clients struggle with how to combine market work and family work. It will change the way you educate, normalize, and approach this issue with clients.").

90. See Cahn, Power of Caretaking, supra note 82, at 182-83, 192-98 (arguing that women retain commitments to caretaking).

91. Schultz, Life's Work, supra note 1, at 1908. 
an important bit of legal history: When post-divorce entitlements were cut back after the "divorce revolution" of the 1970s, ${ }^{92}$ this did not prevent women from staying home. Rather, it simply impoverished those who did, leaving nearly forty percent of today's divorced mothers in poverty. ${ }^{93}$

\section{The Family Wage Gap Between Mothers and Other Adults}

Schultz associates the claim that motherhood creates economic penalties solely with conservative human capital theorists who defend traditional gender roles as efficient, and argues that these are the authors whom joint property theorists "tend to" reference. ${ }^{94} \mathrm{ln}$ fact, my analysis relies on recent work by economist Jane Waldfogel. ${ }^{95}$ ln a series of articles, Waldfogel documented that while "the gap in pay between women and men has been narrowing, the gap between women with children and those without children has been widening" in the past few decades. ${ }^{96}$ "Having children had positive or no effects for men, but very strongly negative effects for women, and these effects increased from 1980 to 1991." ${ }^{27}$ By 1991, the pay gap between mothers and others was larger than the pay gap between men and women. ${ }^{98}$ Single mothers (whether never married or divorced) fare worse than married mothers. ${ }^{99}$

If Schultz disputes Waldfogel's findings, it may be more useful to articulate her reasons for challenging these findings than to charge that fellow feminists who rely on them are blindly following human capital theory. Feminists need only deny that family roles account for part of women's economic disadvantage if they adhere to the traditional view that women's "choice" disproves the existence of gender discrimination. ${ }^{100}$ But it does not.

Say, in a segregated country, there are two drinking fountains, one for whites only. If a person of color walks up to the other, that is a

92. The divorce revolution both cut back on alimony and changed the practice of awarding the family house to custodial wives. See Lenore J. Weitzman, The Divorce Revolution 73, 143-44 (1985).

93. Kurz, supra note 45 , at 3 .

94. Schultz, Life's Work, supra note 1, at 1903.

95. Williams, Unbending Gender, supra note 2, at 2.

96. Jane Waldfogel, Understanding the "Family Gap" in Pay for Women with Children, 12 J. Econ. Persp. 137, 137 (1998) [hereinafter Waldfogel, Family Gap]; see also Jane Waldfogel, The Effect of Children on Women's Wages, 62 Am. Soc. Rev. 209, 209 (1997) ("There is also a persistent 'family gap'; that is, mothers earn lower hourly wages than do women without children.").

97. Waldfogel, Family Gap, supra note 96, at 147.

98. 1 d. at 148 .

99. ld. at 144. This is not surprising. The ideal-worker norm is hard on married mothers, but single mothers are the most disadvantaged by a system that defines its workplace ideals in terms of a worker who is supported by a flow of family work from a nonemployed or marginally employed wife.

100. The best known theorists of the popular notion that women's "choice" disproves the existence of gender discrimination are the human capital theorists. For Schultz's discussion, see Schultz, Life's Work, supra note 1, at 1893-98. 
choice. But that choice does not negate the existence of discrimination. ${ }^{101}$ Similarly, if employers define the ideal worker as someone who takes no time off for childbearing or childrearing, they are framing their ideal worker as someone with the body and traditional life patterns of a man. Regardless of mothers' choices, that is sex discrimination. ${ }^{102}$

\section{E. What's the Fight About?}

What Schultz depicts as an epic struggle between the forces of traditionalism and the forces of liberation is, in fact, something more subtle. As 1 have noted above, what's involved is a fight between the femmes and the tomboys.

The group Schultz calls joint property feminists ${ }^{103}$ - more accurately called care work advocates-rejects the strategy of empowering women by requiring them to abandon traditionally feminine gender performances. Some care work advocates are femmes who embrace the traditional allocation of caregiving to women. ${ }^{104}$ Others are tomboys who feel solidarity with femmes, either because they see the devaluation of femininity as very close to the devaluation of women or because they feel that, to be effective or to be respectful, they need to meet feminine women on their own ground rather than insisting that women embrace the traditions of masculinity. ${ }^{105}$

In my view, American feminists have little choice but to take traditionally feminine gender performances as a given, for a simple reason: The traditions of femininity have proven remarkably persistent. Today, two out of three mothers are employed less than forty hours a week during the key years of career advancement-and eighty-five percent of women become mothers. ${ }^{106}$ ln an economy where many of the best jobs

101. Critical race scholars have often pointed out that analogies between race and sex need to be used with caution. See Devon Carbado, Black Rights, Gay Rights, Civil Rights, 47 UCLA L. Rev. 1467, $1489 \mathrm{n} .79$. My use of the drinking fountain analogy is not meant to imply that the disadvantages associated with motherhood are identical to those associated with the American apartheid. I use the analogy for a limited purpose: to deconstruct the choice argument that is so powerful in the gender context-but transparently ludicrous in the context of race.

102. Actually, it is gender discrimination: defining the ideal worker in that way polices men back into breadwinner roles as it polices women out of them.

103. Schultz, Life's Work, supra note 1, at 1907-08.

104. See, e.g., Fineman, The Neutered Mother, supra note 13, at 87-89, 230-33 (opposing the "neutering" of "Mother," and making it clear that her goal is to empower women in their traditional mothering role); Mary Becker, Caring for Children and Caretakers, 76 Chi.-Kent L. Rev. 1495, 1512 (2001) (self-identifying as a theorist who advocates empowering mothers in their traditional role because she is "skeptical of the likelihood of men actually engaging in equal parenting").

105. See, e.g., Williams, Unbending Gender, supra note 2, at 146-50 (arguing for the importance of creating coalitions among women who live according to the traditions of femininity, and those who challenge those traditions).

106. Williams, Unbending Gender, supra note 2, at 2 (stating that the figure is nearly ninety percent). 1 used the eighty-five percent figure on the advice of demographer 
(blue as well as white collar) require overtime, overtime work among mothers is rare: ninety-two percent work less than fifty hours a week. ${ }^{107}$ We law professors may be tomboys, but the femmes are going strong. ${ }^{108}$

\section{Changing the Role of Personal Narrative in Feminism: Why THEORY MATTERS}

How can we avoid a new round of sameness/difference debates between femmes and tomboys? One way is to pay closer attention to theory. Richard Rorty often says that theory does not matter. ${ }^{109} \mathrm{He}$ is wrong. Theory matters a lot.

The viewpoint I have been articulating stems from pragmatist theory, which is premised on the notion that every viewpoint is situated and therefore partial. ${ }^{110}$ Every truth reflects a specific subject position; most theorists start from their own (although some do not: Lucie White is a good example). ${ }^{111}$

While theorists typically start from their own subject position, they should not end there. For example, women law professors in traditionally masculine white-collar jobs, citing studies of women in traditionally masculine blue-collar jobs, should not assume that all women are, or want to be, as work-identified as they are.

Not only are other people's truths partial. Mine are too. How can we build a feminist theory that reflects the situated nature of truth in a world where women are in very different subject positions?

Suzanne Bianchi. For more recent statistics, see Lynne M. Caspar \& Suzanne M. Bianchi, Continuity \& Change in the American Family 72 tbl.3.1 (tabulating cumulative fertility patterns) (forthcoming 2002); id. at 75 tbl.3.3 (tabulating first-birth probabilities for childless women).

107. Williams, Unbending Gender, supra note 2, at 2.

108. Schultz relies on traditional statistics of full-commodification feminism, which veil the extent of women's continuing marginalization by treating the crucial divide as one between women who are in the workforce and those who are not. Schultz, Life's Work, supra note 1, at $1906 \mathrm{nn} .82 \& 86-87,1908 \mathrm{nn} .92-96$. Two key points: First, many women in the workforce are in marginalized part-time or mommy track jobs; second, workforce participation figures gloss over the very high proportions of mothers who are marginalized during the key job-building years. This is why, with the kind assistance of economist Manuelita Ureta and demographer Suzanne Bianchi, 1 have generated a new data series documenting the high level of economic marginalization among mothers by asking not how many women are employed (i.e., putting part-time workers in the same category as full-time workers) but by asking instead how many women are marginalized (lumping parttimers with mothers at home, based on the punitive conditions that currently exist in parttime work). Space constraints prohibit me from developing this point further here, and from even mentioning it in the text.

109. Richard Rorty, Contingency, Irony, and Solidarity xiv-xvi (1989).

110. Williams, Unbending Gender, supra note 2, at 260-70.

111. See generally Lucie White, Quality Child Care for Low-Income Families: Despair, Impasse, Improvisation, in Hard Labor: Women and Work in the Post-Welfare Era 116 (Joel F. Handler \& Lucie White eds., 1999) (analyzing the experience of lowincome women, based on interviews). 
Just because a given viewpoint seems indubitably true based on our own lives or the lives of our mothers, we cannot generalize that viewpoint into a prescription for all women.

If the goal is to create an effective coalition to improve the economic position of women, one key is to bridge the divide between women with a workplace identity and women without one. This requires an empathetic stance in which women identified with a job are open to the truths of women without jobs, and family-identified women are open to the truths of women who retain commitments both to family work and market work. Bridging this divide is a crucial first step if the goal is to forge an effective coalition.

Schultz writes from an older, transcendentalist tradition in which nineteenth-century treatise writers and twentieth-century law professors tell people what to do. This role works well when what is at issue is the "mailbox rule." That is to say, people are willing to let treatise writers and law professors tell them whether an offer should be valid on dispatch or upon receipt, fundamentally because it does not matter what the rule is so long as everyone agrees on A or B.

But the issues Schultz discusses in "Life's Work" do not involve an arbitrary commercial rule. Her topic is how people should live their lives. On issues as intimate as those involving work and family, the question is how to persuade people to rethink the warp and woof of their daily lives.

We are lawyers; it should not be big news that the way to reach an audience is to send a message that you understand their concerns and respect their divergent truths. What we need is not a pronouncement, no matter how sincerely felt. We need a listening tour. As I have written elsewhere:

For me, the key insight is that I do not know everything about what is best for women. I have a few basic commitments-to equal opportunities for meaningful (market and family) work, to equal entitlements to bodily integrity, to ending the eroticizing of dominance. Beyond that, I tack back and forth, bargaining with my traditions, much as other women do. Like them, I try to do the best I can. ${ }^{112}$

All women are the products of our gender traditions. We are simultaneously liberated by them, oppressed by them, and constructed by them. To use an image common among philosophers: Even if we need to rebuild the boat, we must remember we are in the middle of the sea. The very natural fear is that, if we tear down too much, we will sink like a stone.

We need to respect divergent deals women strike with their gender traditions, and recognize that each of us has made trade-offs she would prefer not to have had to make. This philosophy creates a very different 
tone, and a different set of policy mandates, than one that assumes that the theorist can deduce and deliver the "Truth About Gender."

The only alternative to respectful listening is a series of gender wars in which each woman will criticize those a bit more work-identified than she for callously disregarding her family's needs, and each woman will criticize those a bit more family-identified than she for reinforcing stereotypes. With a thousand different points on the work/family continuum, the resulting gender wars will preclude social change. To build a coalition capable of improving the economic position of all women, we need to meet women where they are and respect their divergent truths-which are as flawed and situated as our own.

In particular, women as work-identified as the typical law professor need to remember that we have it easy: We have had access to jobs that are highly-paid, high-status, and extraordinarily flexible (at least after tenure). We do not have jobs where, once we are at work, we cannot even make a phone call to check whether our kids, at home alone, are okayas is true of many low-income women. Nor do we have jobs where the "full-time" option requires working such long hours of overtime that we rarely see our children awake, as is the case with many blue-collar workers in unionized factory jobs ${ }^{113}$ and many practicing professionals. ${ }^{114}$

Moreover, few tenured law professors face the depressing interaction most women face: the demoralizing combination of inadequate child care, a flawed system for delivering child services, and exploitative conditions on the job. ${ }^{115}$

1. Inadequate Child Care. - Said one working-class mother:

It's the best we can afford, but it's not great because she keeps too many kids, and I know they don't get good attention. Especially the little one. . . . She's so clingy when I bring her home; she can't let go of me, like nobody's paid her any mind all day. ${ }^{116}$

Even people who can pay high salaries have trouble. I suspect we all know women who have quit in exhaustion after a long succession of nannies. Alarmingly, studies have determined that much of the child care available in the U.S. is "poor to mediocre."117 In fact, a national study exposed that one out of three family child care programs in the U.S. is inadequate, i.e. poor enough to actually harm child development. ${ }^{118}$

2. Moms in Cars. - In France, well-baby care is delivered in high-quality child care centers. In the U.S., parents (mostly mothers) typically have to take time off from work, not only to

113. 1d. at 80 .

114. 1d. at 71 .

115. Joan Williams, Majority Rule?, Legal Times, Sept. 3, 2001, at 33.

116. Williams, Unbending Gender, supra note 2, at 154.

117. Children's Defense Fund, Child Care Basics, at http://www.childrensdefense. org/cc_facts.htm (last visited Mar. 10, 2002) (on file with the Columbia Law Review).

118. Id. 
take kids to the doctor but to other enrichment activities that play so large a part in middle-class life. The system of delivering child services through moms in cars is punitive towards poor families, and burdensome even on many middle-class families. Said one secretary, "If you can afford the cut in pay for the hours, the ideal situation would be to get home when they get home from school, 3 P.M., so you can take them to ballet and Boy Scouts."119 A recent study of families in a wide range of income levels found that one of the most frequent reasons parents took time off from work was to provide transportation. ${ }^{120}$

3. Exploitative Working Conditions. - Going to work is no picnic for many women. High-status workers face glass ceiling problems; women of all classes face sexual harassment and the maternal wall. ${ }^{121}$ What is the point of knocking oneself out, and penalizing one's kids to boot, when work seems an uphill battle? (Note that in this context, the persistence of sex discrimination reinforces the notion that women are not serious workers, thereby providing the rationale for further sex discrimination.)

This is the social context of most women's lives. These social conditions are combined with gender performance norms that define men in terms of their ability to succeed at work, and women as people who should have "all the time and love in the world to give" to their children. ${ }^{122}$

In view of all this, it is hard to be judgmental about which women are making the "right choices," and it is simply not convincing to say that employer behavior is the sole social force constructing women's "choices." ${ }^{23}$ The crucial point-politically, strategically, and ethicallyis that a variety of different social forces feed into the choices made by women, including not only employer behavior but also the lack of social supports for childrearing and gender performance norms. We need not adopt a simplistic model that employer behavior alone creates women's "choices." We need only point out that every choice currently available is deeply flawed, and that an employer who defines the ideal worker as someone who takes no time off for childbirth or childrearing is defining

119. Williams, Unbending Gender, supra note 2, at 34 .

120. Jody Heymann, The Widening Gap: Why America's Working Families Are in Jeopardy and What Can Be Done About It 190 (2000).

121. Schultz, Reconceptualizing Sexual Harassment, supra note 73, at 1687; see also Williams, Unbending Gender, supra note 2, at 69 (defining glass ceiling practices as "different treatment of men and women with respect to job assignments that lead to advancement, initial placement in relatively dead-end jobs, and lack of mentoring for women").

122. Williams, Unbending Gender, supra note 2, at 30; see also Diane Kobrynowicz \& Monica Biernat, Decoding Subjective Evaluations: How Stereotypes Provide Shifting Standards, 33 J. Experimental Soc. Psych. 579, 584-87 (1997) ("A 'Good Mother' [is] more likely than a 'Good Father' to be described as willing to always be there and to do anything for the children . ..." (italics omitted)).

123. Schultz, Life's Work, supra note 1, at 1904. 
his work ideals around the bodies and life patterns of men in a manner that systematically discriminates against women.

\section{ConClusion}

According to the biographer of the thirty-sixth president of the United States, Lyndon Baines Johnson was often cruel to his wife Lady Bird. He routinely humiliated her in public contexts, saying things like, "It's snowing down South"- the old-fashioned phrase used to tell someone her slip was showing. ${ }^{124}$

When I was growing up, I worried not only about my slip but also about my bra. At the age of ten, I remember apprehensively asking my best friend (who was far more socially adept than I): "What do you do if you are out with a boy and you find your bra strap showing?" "Just make a joke of it," she said. "Say: 'I'm going to be a Playboy bunny.'"

In some ways women's dress has changed very little; in other ways it has changed a lot. Girls and women no longer feel they will be humiliated if a slip or a bra "shows." How did we solve that problem? We stopped apologizing for who we are. If your sports bra is designed to show, anyone who tries to humiliate you because it is showing is just weird.

It is time we used the same strategy for motherhood. For forty years we have tried to paper it over, to hide it, and to deny it. This enabled people to discredit and humiliate (not to mention impoverish) us whenever our motherhood showed through.

The time has come to stop trying to hide, to stop trying to pass. No woman should be compelled to do care work. But most women end up doing a lot of it. Penalizing them for doing so is sex discrimination.

124. Interview by Daniel Zwerdling with Jan Jarboe Russell, biographer of Claudia “Ladybird" Johnson, on All Things Considered, National Public Radio (Aug. 22, 1999). 